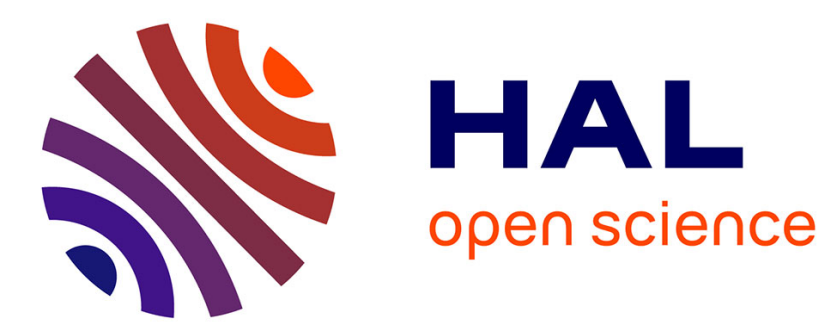

\title{
HER-family gene amplification and expression in resected pancreatic cancer
}

\author{
E.A. Te Velde, A.C. Franke, R. van Hillegersberg, S.M. Elshof, R.W. de
} Weger, I.H.M.Borel Rinkes, P.J. van Diest

\section{To cite this version:}

E.A. Te Velde, A.C. Franke, R. van Hillegersberg, S.M. Elshof, R.W. de Weger, et al.. HER-family gene amplification and expression in resected pancreatic cancer. EJSO - European Journal of Surgical Oncology, 2009, 35 (10), pp.1098. 10.1016/j.ejso.2009.02.013 . hal-00556285

\section{HAL Id: hal-00556285 \\ https://hal.science/hal-00556285}

Submitted on 16 Jan 2011

HAL is a multi-disciplinary open access archive for the deposit and dissemination of scientific research documents, whether they are published or not. The documents may come from teaching and research institutions in France or abroad, or from public or private research centers.
L'archive ouverte pluridisciplinaire HAL, est destinée au dépôt et à la diffusion de documents scientifiques de niveau recherche, publiés ou non, émanant des établissements d'enseignement et de recherche français ou étrangers, des laboratoires publics ou privés. 


\section{Accepted Manuscript}

Title: HER-family gene amplification and expression in resected pancreatic cancer

Authors: E.A. te Velde, A.C. Franke, R. van Hillegersberg, S.M. Elshof, R.W. de Weger, I.H.M.Borel Rinkes, P.J. van Diest

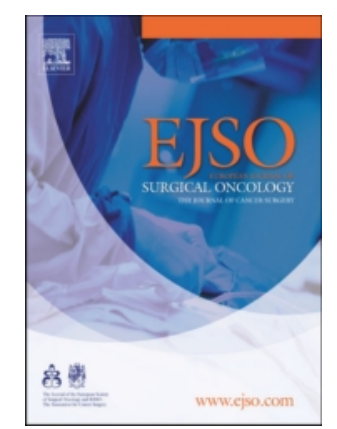

PII: $\quad$ S0748-7983(09)00074-2

DOI: $\quad$ 10.1016/j.ejso.2009.02.013

Reference: $\quad$ YEJSO 2804

To appear in: European Journal of Surgical Oncology

Received Date: 16 October 2008

Revised Date: 19 February 2009

Accepted Date: 23 February 2009

Please cite this article as: te Velde EA, Franke AC, van Hillegersberg R, Elshof SM, de Weger RW, Rinkes I.H.M.B, van Diest PJ. HER-family gene amplification and expression in resected pancreatic cancer, European Journal of Surgical Oncology (2009), doi: 10.1016/j.ejso.2009.02.013

This is a PDF file of an unedited manuscript that has been accepted for publication. As a service to our customers we are providing this early version of the manuscript. The manuscript will undergo copyediting, typesetting, and review of the resulting proof before it is published in its final form. Please note that during the production process errors may be discovered which could affect the content, and all legal disclaimers that apply to the journal pertain. 


\title{
HER-family gene amplification and expression in resected pancreatic cancer
}

\author{
E. A. te Velde ${ }^{1}$, A.C. Franke ${ }^{1}$, R. van Hillegersberg ${ }^{1}$, S. M. Elshof ${ }^{2}$, \\ R. W. de Weger ${ }^{2}$, I. H.M. Borel Rinkes ${ }^{1}$, P. J. van Diest ${ }^{2}$ \\ ${ }^{1}$ Department of Surgery, ${ }^{2}$ Department of Pathology, University Medical Centre Utrecht, Utrecht, The \\ Netherlands
}

Address of correspondence:

Richard van Hillegersberg ${ }^{1}, \mathrm{MD}, \mathrm{PhD}$

Heidelberglaan 100

3584 CX Utrecht

The Netherlands

T: +31 (0)88-75 56968

F: +31 (0)88-75 55459

Email: R.vanHillegersberg@umcutrecht.nl 


\section{Abstract}

Aims: Despite surgical resection, pancreatic cancer carries a poor prognosis. In search for new molecular therapeutic targets, we investigated the expression of the HER-family and gene amplification of HER-2 in pancreatic adenocarcinomas of different stages.

Methods: Tissue of 45 resected patients was analysed for all HER-family 1-4 expression by immunohistochemistry and HER-2 gene amplification was assessed by multiplex ligation-dependent probe amplification and chromogenic in situ hybridization. The type of surgery, location, stage and grade of the tumour, as well as involvement of the resection margins were correlated with HERexpressions and univariate and multivariate survival analysis performed.

Results: Normal pancreatic tissue lacked HER1-2 expression, but did show HER3-4 expression. In cancers, no membranous overexpression of HER-1 and HER-2 was seen nor gene amplification of HER-2 found. HER-3, HER-4 is physiologically expressed in the normal pancreas and loss of cytoplasmic HER-3 and HER-4 expression was seen in 33/45 (73\%) and 8/45 (18\%) of pancreatic cancers. Cytoplasmic HER-3 expression decreased from early to late stage $(p=0.05)$. HER-4 expression was not associated with survival, stage or tumor grade. There were no statistically significant differences in HER1-4 expression between the papilla of Vater $(n=13)$ and non-papilla cancers $(n=32)$. Multivariate survival analysis showed only stage to be of independent prognostic value $(p=0.015)$.

Conclusions: HER-1 and HER-2 are not overexpressed in pancreatic cancers. HER-3 and HER-4 are expressed in the normal pancreas but expression is lost in pancreatic cancer. HER-targeted therapy in pancreatic cancer is not supported by HER-expression of the tumour.

Keywords: HER-1, HER-2, HER-3, HER-4, EGFR, pancreatic cancer, immunohistochemistry, gene amplification, therapy. 


\section{Introduction}

Ductal adenocarcinoma of the pancreas has the poorest long-term survival of all known types of cancer with a median survival of 3-10 months and a 5-year survival rate ranging from $0.4 \%$ to $4 \%$.[13] The incidence of pancreatic cancer is increasing in the Western world, and at present it is one of the top five of cancer related death causes with approximately 19.000 deaths each year.[2] Due to late presentation, tumors are often locally advanced and/or have metastasized at time of diagnosis. Therefore, only $10 \%$ of the patients is eligible for surgical resection. [1;3] The only possible curative therapy is a pancreaticoduodenectomy, which improves chances of survival. However, even after surgical resection the 5-year survival rate is only 7-34\%.[3]

Extensive studies have been done to identify new targets for adjuvant therapy of pancreatic cancer. [2;4] To date, systemic chemotherapy has however been ineffective, except for gemcitabine, which has a modest effect on survival and tumor related symptoms.[4]

Novel agents specifically directed against molecular targets such as growth factor receptors have yielded promising results in several forms of cancer. [5] Such growth factors influence processes like tumor growth, apoptosis and metastasis formation. [6;7] and their overexpression therefore confers a worse prognosis. [6]

The transmembrane growth factor receptors HER-1 (also known as the epidermal growth factor receptor (EGFR) or c-erbB-1), HER-2/neu (also known as c-erbB-2), HER-3 (c-erbB-3) and HER-4 (cerbB-4) contain an extracellular ligand binding domain, a transmembrane region and an intracellular with intrinsic protein-tyrosine kinase activity. [8]

In pancreatic cancer HER-1 overexpression has been described in $30 \%$ to $68 \%$ of tumours $[9 ; 10]$ and has been reported to be correlated with advanced stage. [11]

HER-2 overexpression and gene amplification is usually correlated with advanced stage, presence of metastases and a poor prognosis, but for overexpression in the absence of gene amplification this is less clear. [12;13] Percentages of pancreatic cancer cases with HER-2 overexpression in the literature vary between 0 and $82 \%$. [3;6;7] The number of pancreatic cancer studies that found a significantly poorer survival rate in patients with HER-2 overexpression equals that of those that did not find such significant difference. [6;7;14;15]

HER-3 was found to be overexpressed in cancers in various organs including breast, lung and stomach with unclear prognostic significance. [8] A few pancreatic cancer studies found overexpression of HER-3 [16-19] which was associated with advanced tumor stage and shortened survival. [16]

HER-4 is predominantly expressed in normal skeletal muscle, heart, pituitary, brain and cerebellum, as well as in several breast cancer cell lines. [20] Little is known about HER-4 expression in pancreatic cancer. Overexpression of HER-4 in cancer cells has been described in pancreatic tumor samples in a few studies and like HER-3, the prognostic significance remains unclear. [19;21] The aim of this study was therefore to investigate expression of the complete HER-family in pancreatic cancer in order find new molecular targets for adjuvant therapy to improve survival after surgical resection of pancreatic cancer. 


\section{Patients and methods}

\section{Patients and tissue samples}

All consecutive patients who underwent surgery in the University Medical Center in Utrecht, the Netherlands, for primary tumors of the pancreas in the period January 2000 until August 2006 were included. The following clinicopathological data were recorded: age, sex, type of surgery, localization, stage according to the TNM classification, differentiation grade of the tumor, radicality of the resection and survival.

Freshly removed tissue samples were fixed in neutral buffered formaldehyde and paraffin-embedded for morphological assessment, immunohistochemistry and multiplex ligation-dependent probe amplification (MLPA). Use of anonymous or coded left over material for scientific purposes is part of the standard treatment contract with patients in our hospital.

\section{Immunohistochemistry}

The tissue block with the highest tumor percentage based on the H\&E sections was selected by the pathologist for further analysis. Serial sections $(4 \mu \mathrm{m})$ were placed onto silanated glass slides. Table 1 shows the different antibodies and methods used. Appropriate positive and negative controls were used throughout. Negative controls were obtained by omission of the primary antibodies.

Briefly, all slides were deparaffinized, rehydrated and treated with antigen retrieval buffer for 20 minutes. Next, the slides were incubated with peroxidase-blocking buffer to stop endogenous peroxidase activity and subsequently with the primary monoclonal antibodies. For HER-1 this was done in a BondMax autostainer (Vision Biosystems), after which slides were incubated with postprimary for 8 minutes and then for 8 minutes with the polymer. For HER-2, visualization of the peroxidase label was accomplished by incubation with visualization reagens (DAKO) for 30 minutes. For HER-3 and HER-4, signal was visualized using the DAKO-EnVision Kit. Staining was developed with di-amino-benzidin. Finally, the slides were counterstained with hematoxylin.

The slides were scored by two observers blinded to the clinicopathological data. HER-1 overexpression was defined as presence of complete membrane staining of tumor cells. HER-2 membrane staining was scored according to the DAKO scoring system. For HER-3 and HER-4, cytoplasmic staining was semiquantitatively scored as negative or $1+, 2+$ or $3+$. Strong expression was defined as $2+$ or $3+$ expression.

\section{HER-2 gene amplification}

HER-2 gene amplification was assessed in all cases by multiplex ligation-dependent probe amplification as described before and the MLPA technique has been described elsewhere. [22] The MLPA test for HER-2 amplification was obtained from MRC-Holland (Amsterdam, The Netherlands). The P004 probe mix contains three sets of hemi-probes that recognize different sequences of the human HER-2 gene. Briefly, $50-500 \mathrm{ng}$ of target DNA per $5 \mu \mathrm{l}$ of $10 \mathrm{mM} \mathrm{pH} 8$ Tris $0.1 \mathrm{mM}$ EDTA was denaturated for 5 minutes at $98^{\circ} \mathrm{C}$ after which $3 \mu$ of the probe mix was added. The mixture was heated at $95{ }^{\circ} \mathrm{C}$ for 1 minute and incubated at $60{ }^{\circ} \mathrm{C}$ overnight. Ligation was performed with the 
temperature stable Ligase-65 enzyme (MRC-Holland) for 15 minutes at $54^{\circ} \mathrm{C}$. Next, the ligase was heat inactivated in the thermocycler for 5 minutes at $98^{\circ} \mathrm{C}$. Ten microliters of the ligation mixture was premixed with $30 \mu \mathrm{l}$ of PCR buffer and put in a PCR machine at $60{ }^{\circ} \mathrm{C}$. Subsequently, a $10 \mu \mathrm{l}$ mix was added that contained deoxynucleoside triphosphate, Taq polymerase, and one unlabeled and one carbofluorescein labeled PCR primer complementary to the universal primer sequences. PCR was carried out for 33 cycles ( 30 seconds at $95^{\circ} \mathrm{C}, 30$ seconds at $60{ }^{\circ} \mathrm{C}$, and 1 minute at $72{ }^{\circ} \mathrm{C}$ ). The fragments were analyzed with the $3130 \mathrm{xl}$ Genetic Analyser. Fragment analysis was performed using Genescan software. DNA of a known amplified breast cancer was used as a control sample and analyzed simultaneously with pancreatic cancer in each run.

To objectify interpretation of the fragment analysis, the relative quantity of the amplified probes in each sample was determined using an Excel template. For this purpose, the relative peak areas for each probe were calculated as fractions of the sum of peak areas in a given sample. Subsequently, the fraction of each peak was divided by the average peak fraction of the corresponding probe in control samples. Finally, the values were normalized using the values obtained for the autosomal control probes that served as a reference for the copy number of 2.0. Cases that showed a copy number greater than 2 for at least two of the probes on the HER-2 locus were considered amplified. Chromogenic in situ hybridization (CISH) for copy number analysis of the HER-2 gene was performed according to the manufacturer's instructions with the Zymed kit when no definitive conclusion could be reached on HER-2 amplification status with MLPA and on cases with low cellularity. Briefly, $4 \mu \mathrm{m}$ paraffin slides were deparaffinized and rehydrated. All slides were cooked in Heat Pretreatment and incubated with Enzyme Pretreatment. Next, they were dehydrated and after that $15 \mu \mathrm{HER}-2$ probe was added. The probe was denaturated for 6 minutes at $95^{\circ} \mathrm{C}$, whereafter the slides were incubated overnight at $37^{\circ} \mathrm{C}$. For 5 minutes the slides were placed in SSC buffer and then endogenous peroxidase was blocked with $4 \%$ hydrogen peroxide for 15 minutes. Slides were washed with PBS Tween $(0.05 \%)$ and incubated with CAS-block (10 minutes). Next, the slides were incubated with mouse-anti-DIG for 30 minutes. After washing with PBS Tween, they were incubated with HRP-antimouse for another 30 minutes, washed and DAB was added (30 minutes). Then, the slides were counterstained with Mayer's hematoxylin, dehydrated and coverslipped in Histomount. Scoring was done according to the manufacturer's instructions.

\section{Statistical analysis}

The chi-square test was used to compare frequency distributions. Multivariate survival analysis was done using the Cox regression method. P-values below 0.05 were considered significant. Statistical analysis was carried out using SPSS software. 


\section{Results}

\section{Patients and tissue samples}

The clinicopathological data of all patients is displayed in table 2. Pancreatic cancer tissues were obtained from 45 patients, 26 males and 19 females. Median age was 62 years (range 33-76). Twenty-six patients were diagnosed with a pancreatic head tumor, 6 with a body and/or tail tumor, and 13 were papilla of Vater cancers. A pancreaticoduodenectomy was performed in 38 cases, a distal and/or body resection in 4 cases and an incision biopsy only in 3 cases. Of the surgically removed tumors, margins were free in 24 cases, microscopically involved in 17 cases and macroscopically involved in 1 case. There were 2 stage I, 39 stage II, 1 stage III and 0 stage IV tumors. In three cases with biopsy only, definitive staging could not be determined. Tumor grading showed 13 well-differentiated, 15 moderately differentiated and 17 poorly differentiated tumors. None of the patients received chemotherapeutic treatment prior to or after surgery. Median survival was 13.5 months (range 4 days - 77 months).

\section{Immunohistochemistry}

Table 3 summarizes the expression and amplification status of HER-1, HER-2, HER-3 and HER-4, figure 1 visualizes our findings. No cell membrane reactivity of HER-1 was observed. Four cases showed HER-2 1+ membrane staining, but no overexpression was found.

HER-3 showed mainly cytoplasmic and occasionally membrane staining. Expression was strong in normal pancreatic tissue, mainly in islets and ducts. HER-3 cytoplasmic staining was negative in 12 cases $(27 \%), 1+$ in $21(46 \%), 2+$ in $8(18 \%)$ and $3+$ in $4(9 \%)$ tumors. Strong expression of HER-3 was thus seen in $12(27 \%)$ tumors. Membranous HER-3 staining was only visible in $3(7 \%)$ tumors (all non-papilla cases), all these tumors showed also at least 2+ cytoplasmic staining.

HER-4 showed mainly cytoplasmic and occasionally membrane staining. Expression was strong in normal pancreatic tissue, and was seen in islets as well as exocrine tissue. HER-4 staining was absent in 4 tumors (9\%), 1+ in 4 (9\%), 2+ in $21(47 \%)$ and $3+$ in $16(35 \%)$ tumors. Reduced expression of HER-4 $(0 / 1+)$ was thus seen in $8(18 \%)$ of the tumors. Membranous HER-4 staining was seen in 4 (9\%) tumors (all non-papilla cases), all of these tumors showed also at least $2+$ cytoplasmic staining. Two out of the 3 cases that had membranous HER-3 staining, also had membranous HER-4 staining. 


\section{HER-2 multiplex ligation-dependent probe amplification (MLPA)/CISH}

Tissue samples of 40 patients contained enough tumor to perform MLPA. In these samples no HER-2 gene amplification was found. In the five remaining tissues with a small percentage of tumor, $\mathrm{CISH}$ did not show gene amplification.

\section{Clinicopathologic correlations of HER-3/HER-4 expression}

Cytoplasmic expression of HER-3 decreased significantly ( $p=0.01)$ from early (stage IA, IB and IIA) to late stage (IIB and III). There were no statistically significant differences between cytoplasmic expression of HER-3 or HER-4 and other clinicopathologic features.

In univariate survival analysis, only (early vs late) stage $(p=0.05)$ and radicality $(p=0.0041)$ were significant, and none of the other clinicopathologic features had prognostic value. In multivariate survival analysis including stage, grade, localisation and HER-3/4 expression, only stage had independent prognostic value $(p=0.015)$ and no other features were selected. 


\section{Discussion}

In this study we investigated the expression of the HER-family (HER 1-4) and gene amplification of HER-2 in pancreatic adenocarcinomas, mostly derived from pancreaticoduodenectomy procedures. HER-1 and HER-2 showed no overexpression. HER-3 and HER-4 on the other hand showed a relative loss of their usual high expression in normal pancreas ( $28 \%$ and $79 \%$ respectively).

\section{Expression of HER-1}

For HER-1 this result is in contrast with the majority of published series which show overexpression of HER-1 in 30-68\% of pancreatic adenocarcinomas.[11;17] However, Prenzel et al. also found down regulation in mRNA expression of HER-1 in malignant pancreatic tissue compared to normal tissue using quantitative RT-PCR. [23] Expression regulation of HER-1 is however complicated. Mutation and amplification of HER-1 in cancer is relatively rare, [24;25] a repeat in the first intron has an expression regulating function [24] and different commercially available antibodies may yield quite different expression patterns and clinical value[25] . We believe that this data gives strong evidence for the absence of overexpression in resection specimens of pancreatic cancer patients.

Erlotinib (Tarceva $\left.{ }^{\circ}\right)$ is a monoclonal antibody directed against HER-1 that has recently been approved as an adjuvant treatment in metastatic pancreatic cancers in combination with gemcitabine. A fase III study with Erlotinib showed a $22 \%$ longer survival, a 1 -year survival of $23 \%$ versus $19 \%$, and $30 \%$ progression free survival with the combination versus gemcitabine alone. [26] Indeed, in that study, the EGFR status was not associated with response or disease stability. In view of our present results, determination of overexpression in order to determine patients qualifying for Erlotinib might not be clinically relevant.

\section{Expression of HER-2}

Studies on HER-2 have, like HER-1, yielded conflicting results. According to our results, Potti et al. [27] did not detect overexpression of HER-2 in 33 pancreatic cancer patients. Day et al. described decreasing HER-2 expression from $100 \%$ in carcinoma in situ to $0 \%$ in poorly differentiated invasive carcinoma.[28] In other studies, HER-2 expression up to $82 \%$ was described. [6;7;29;30] The differences between these conflicting studies [11;15;17;28;30-32] may therefore be due to differentiation grade, but may also in part be explained by the definition of HER-2 overexpression. We followed the generally accepted DAKO score regarding only $3+$ membrane staining as overexpression, whilst in older studies the cut-off for overexpression was often 1+ [30] and/or cytoplasmic staining was also considered as overexpression[11;15;31-34] . In addition, Saxby et al.[7] found in a summary of literature that twelve different antibodies were used in seventeen different immunohistochemical studies with variable outcome regarding the number of positive samples. The absence of HER-2 overexpression in the present study is corroborated by the lack of gene amplification by MLPA/CISH. This is in line with Yamanaka et al. [11] who also found no gene amplification in 76 pancreatic tumors using southern blot analysis, and the low frequency of 
amplification in the studies of Safran et al. [6] and Saxby et al. [7] . Overall, gene amplification and true protein overexpression of HER-2 seem to be rare in pancreatic cancers.

Trastuzumab (Herceptin ${ }^{\circledR}$ ) is a recombinant humanized IgG monoclonal antibody directed against the HER-2 oncoprotein. There are three supposed mechanisms of the antitumor effect: antibodydependent cell-mediated cytotoxity, direct growth inhibition induced by suppressing signal transduction through HER-2 binding and antiangiogenic effects.[35] Trastuzumab is mainly used for treatment of patients with breast cancers that overexpress HER-2. [36] A recent preclinical study evaluated HER-2 expression and the effect of trastuzumab in pancreatic cell lines and a mouse model. [37] They concluded that tumor growth was inhibited in 3+ HER-2 overexpression tumors and there was a prolonged survival in this group when using trastuzumab. [37] These effects were increased by combined therapy with gemcitabine. [37] In addition, one clinical study has been performed to investigate the effect of the addition of trastuzumab to gemcitabine as possible adjuvant treatment in pancreatic cancer. [38] This fase II clinical study found a median survival of 7 months in metastatic pancreatic cancer with therapy of gemcitabine and Herceptin compared to 4.4 months without this treatment (not significant). [38] Only four of the patients in that clinical study had 3+ HER2 expression.

\section{Expression of HER-3}

We found cytoplasmic overexpression of HER-3 in $27 \%$ of the tumors. Concordantly, Friess et al. found a significant increase of expression of HER-3 in pancreatic cancer compared to control tissue. [17] In a previous study they showed that strong HER-3 expression was seen in $47 \%$ of pancreatic cancer $(n=58)$ and was associated with an advanced tumor stage and a shorter survival.[16] In the present study, we found a significantly decreased cytoplasmic expression of HER-3 with advanced stage of pancreatic cancer, which is a novel result. Concordantly, a very low expression of HER-3 has also been reported in advanced stage ovarian carcinoma. [39] Loss of HER-3 overexpression might be correlated with progression of pancreatic tumor stage.

\section{Expression of HER-4}

In the present study, strong cytoplasmic overexpression of HER-4 was seen in $82 \%$ of the cancer samples. Membranous staining was seen in only $9 \%$ of the samples (all non-papilla cases). There were no correlations with survival, stage or grade, although the low numbers of patients do not allow firm conclusions with respect to survival differences. The existing literature on HER-4 expression and its prognostic significance in pancreatic cancer is limited and the results are conflicting. [19;21] One study reported that mRNA expression of HER-4 was exclusively found in non-metastatic tumors and expression decreased when the stage was more advanced, [21] whilst another report concluded that HER-4 expression decreased in non-metastatic stages of pancreatic cancer. [19] In both studies, survival was not correlated with HER-4 expression.[19;21] Altogether, it seems that like HER-3, HER4 is physiologically expressed in the normal pancreas and the expression decreases or even disappears in some cancers. 


\section{Future perspectives}

Based on the outcome of the present study it seems that HER-targeted therapy for patients with pancreatic cancer is not supported by HER-expression of the tumor. Alternatively, mutations or amplifications of HER1 (EGFR) may be studied as these may provide a rationale for EGFR targeting therapy. Since for HER2 there is a close correlation between gene amplification and protein expression, and HER3 and HER4 are frequently physiologically expressed in the normal pancreas, few options remain to search for a rationale to target HER2/3/4.

For colorectal cancer further evidence for the lack of usefulness of epidermal growth factor receptor detection by immunohistochemistry was given by others. [40] It has been suggested that pharmacokinetic or pharmacodynamic mechanisms influence tumor delivery of EGFR-therapy. By the use of fluorescent labelled cetuximab as well as PET imaging its in vivo binding was studied in a mouse model. [41;42] Again, in these studies the mismatch of drug delivery and expression of EGFR was confirmed. These authors conclude that pharmacokinetic or pharmacodynamic mechanisms may explain why receptor expression levels alone are not sufficient to predict patient response. In addition, as we know from a meta-analysis of colorectal cancer as well as lung cancer, K-ras mutation downstream of the EGFR receptor is a negative predictor of respons to EGFR therapy. [43] To further elucidate the mechanisms, translational studies in prospective trial patients might provide further insight.

\section{In conclusion}

Pancreatic cancer has a poor prognosis and new adjuvant therapies are needed. In this study of tissue obtained following pancreaticoduodenectomy no overexpression of HER-1 or HER-2 was found. HER-3 and HER-4 are strongly expressed in the normal pancreas but the expression gets lost in some cancers. Cytoplasmic HER-3 expression even decreased from early to late stage $(p=0.05)$. Therefore, clinical use of HER-targeted therapy in pancreatic cancer is not supported by HERexpression of the tumour, and cost-labouring determination of these receptors to select patients suitable for targeted therapy by use of the HER-family might not be indicated.

\section{Conflict of interest}

The authors state that they have no conflict of interest. 


\section{References}

1. Smeenk HG, Tran TC, Erdmann J, van Eijck CH, Jeekel J. Survival After Surgical Management of Pancreatic Adenocarcinoma: Does Curative and Radical Surgery Truly Exist? Langenbecks Arch Surg 2005; 390: 94-103.

2. Stocken DD, Büchler MW, Dervenis $C$ et al. Meta-Analysis of Randomised Adjuvant Therapy Trials for Pancreatic Cancer. Br J Cancer 2005; 92: 1372-81.

3. Garcea G, Neal CP, Pattenden CJ, Steward WP, Berry DP. Molecular Prognostic Markers in Pancreatic Cancer: a Systematic Review. Eur J Cancer 2005; 41: 2213-36.

4. Burris HA3. Recent Updates on the Role of Chemotherapy in Pancreatic Cancer. Semin Oncol 2005; 32: S1-S3.

5. Meric-Bernstam F, Hung MC. Advances in Targeting Human Epidermal Growth Factor Receptor-2 Signaling for Cancer Therapy. Clin Cancer Res 2006; 12: 6326-30.

6. Safran H, Steinhoff M, Mangray S et al. Overexpression of the HER-2/Neu Oncogene in Pancreatic Adenocarcinoma. Am J Clin Oncol 2001; 24: 496-9.

7. Saxby AJ, Nielsen A, Scarlett CJ et al. Assessment of HER-2 Status in Pancreatic Adenocarcinoma: Correlation of Immunohistochemistry, Quantitative Real-Time RT-PCR, and FISH With Aneuploidy and Survival. Am J Surg Pathol 2005; 29: 1125-34.

8. Tovey SM, Witton CJ, Bartlett JM et al. Outcome and Human Epidermal Growth Factor Receptor (HER) 1-4 Status in Invasive Breast Carcinomas With Proliferation Indices Evaluated by Bromodeoxyuridine Labelling. Breast Cancer Res 2004; 6: R246-R251.

9. Salomon DS, Brandt R, Ciardiello F, Normanno N. Epidermal Growth Factor-Related Peptides and Their Receptors in Human Malignancies. Crit Rev Oncol Hematol 1995; 19: 183-232.

10. Uegaki K, Nio Y, Inoue Y et al. Clinicopathological Significance of Epidermal Growth Factor and Its Receptor in Human Pancreatic Cancer. Anticancer Res 1997; 17: 3841-7.

11. Yamanaka Y, Friess H, Kobrin MS et al. Coexpression of Epidermal Growth Factor Receptor and Ligands in Human Pancreatic Cancer Is Associated With Enhanced Tumor Aggressiveness. Anticancer Res 1993; 13: 565-9.

12. Yarden Y, Sliwkowski MX. Untangling the ErbB Signalling Network. Nat Rev Mol Cell Biol 2001; 2: $127-37$.

13. Sauer T, Wiedswang G, Boudjema G, Christensen H, Karesen R. Assessment of HER-2/Neu Overexpression and/or Gene Amplification in Breast Carcinomas: Should in Situ Hybridization Be the Method of Choice? APMIS 2003; 111: 444-50.

14. Lei S, Appert HE, Nakata B et al. Overexpression of HER2/Neu Oncogene in Pancreatic Cancer Correlates With Shortened Survival. Int J Pancreatol 1995; 17: 15-21.

15. Okada N, Ohshio G, Yamaki K, Imamura T, Imamura M. Elevated Serum C-ErbB-2 Protein Levels in Patients With Pancreatic Cancer: Correlation to Metastasis and Shorter Survival. Oncology 1995; 52: 392-6.

16. Friess $\mathrm{H}$, Yamanaka $\mathrm{Y}$, Kobrin MS et al. Enhanced ErbB-3 Expression in Human Pancreatic Cancer Correlates With Tumor Progression. Clin Cancer Res 1995; 1: 1413-20. 
17. Friess $\mathrm{H}$, Wang L, Zhu Z et al. Growth Factor Receptors Are Differentially Expressed in Cancers of the Papilla of Vater and Pancreas. Ann Surg 1999; 230: 767-74.

18. Lemoine NR, Barnes DM, Hollywood DP et al. Expression of the ERBB3 Gene Product in Breast Cancer. Br J Cancer 1992; 66: 1116-21.

19. Thybusch-Bernhardt A, Beckmann S, Juhl H. Comparative Analysis of the EGF-Receptor Family in Pancreatic Cancer: Expression of HER-4 Correlates With a Favourable Tumor Stage. Int J Surg Investig 2001; 2: 393-400.

20. Plowman GD, Culouscou JM, Whitney GS et al. Ligand-Specific Activation of HER4/P180erbB4, a Fourth Member of the Epidermal Growth Factor Receptor Family. Proc Natl Acad Sci U S A 1993; 90: 1746-50.

21. Graber HU, Friess H, Kaufmann B et al. ErbB-4 MRNA Expression Is Decreased in NonMetastatic Pancreatic Cancer. Int J Cancer 1999; 84: 24-7.

22. Purnomosari D, Aryandono T, Setiaji K et al. Comparison of Multiplex Ligation Dependent Probe Amplification to Immunohistochemistry for Assessing HER-2/Neu Amplification in Invasive Breast Cancer. Biotech Histochem 2006; 81: 79-85.

23. Prenzel KL, Warnecke-Eberz U, Brabender J et al. Differential C-ErbB-1 and C-ErbB-2 MRNA Expression in Cancer of the Pancreas Compared With Cancer of the Papilla of Vater. World $\mathrm{J}$ Gastroenterol 2006; 12: 437-42.

24. Brandt B, Meyer-Staeckling S, Schmidt H, Agelopoulos K, Buerger H. Mechanisms of Egfr Gene Transcription Modulation: Relationship to Cancer Risk and Therapy Response. Clin Cancer Res 2006; 12: 7252-60.

25. Kersting C, Tidow N, Schmidt $\mathrm{H}$ et al. Gene Dosage PCR and Fluorescence in Situ Hybridization Reveal Low Frequency of Egfr Amplifications Despite Protein Overexpression in Invasive Breast Carcinoma. Lab Invest 2004; 84: 582-7.

26. Moore MJ, Goldstein D, Hamm J et al. Erlotinib Plus Gemcitabine Compared With Gemcitabine Alone in Patients With Advanced Pancreatic Cancer: a Phase III Trial of the National Cancer Institute of Canada Clinical Trials Group. J Clin Oncol 2007; 25: 1960-6.

27. Potti A, Ganti AK, Tendulkar K et al. HER-2/Neu and CD117 (C-Kit) Overexpression in Hepatocellular and Pancreatic Carcinoma. Anticancer Res 2003; 23: 2671-4.

28. Day JD, Digiuseppe JA, Yeo C et al. Immunohistochemical Evaluation of HER-2/Neu Expression in Pancreatic Adenocarcinoma and Pancreatic Intraepithelial Neoplasms. Hum Pathol 1996; 27: 119-24.

29. Apple SK, Hecht JR, Lewin DN et al. Immunohistochemical Evaluation of K-Ras, P53, and HER-2/Neu Expression in Hyperplastic, Dysplastic, and Carcinomatous Lesions of the Pancreas: Evidence for Multistep Carcinogenesis. Hum Pathol 1999; 30: 123-9.

30. Dergham ST, Dugan MC, Arlauskas $P$ et al. Relationship of Family Cancer History to the Expression of P53, P21WAF-1, HER-2/Neu, and K-Ras Mutation in Pancreatic Adenocarcinoma. Int J Pancreatol 1997; 21: 225-34.

31. Satoh K, Sasano H, Shimosegawa T et al. An Immunohistochemical Study of the C-ErbB-2 Oncogene Product in Intraductal Mucin-Hypersecreting Neoplasms and in Ductal Cell Carcinomas of the Pancreas. Cancer 1993; 72: 51-6.

32. Williams TM, Weiner DB, Greene MI, Maguire HC, Jr. Expression of C-ErbB-2 in Human Pancreatic Adenocarcinomas. Pathobiology 1991; 59: 46-52. 
33. Hall PA, Hughes CM, Staddon SL et al. The C-Erb B-2 Proto-Oncogene in Human Pancreatic Cancer. J Pathol 1990; 161: 195-200.

34. Press MF, Hung G, Godolphin W, Slamon DJ. Sensitivity of HER-2/Neu Antibodies in Archival Tissue Samples: Potential Source of Error in Immunohistochemical Studies of Oncogene Expression. Cancer Res 1994; 54: 2771-7.

35. Kumar R, Yarmand-Bagheri R. The Role of HER2 in Angiogenesis. Semin Oncol 2001; 28: 2732.

36. Slamon DJ, Leyland-Jones B, Shak S et al. Use of Chemotherapy Plus a Monoclonal Antibody Against HER2 for Metastatic Breast Cancer That Overexpresses HER2. N Engl J Med 2001; 344: 783-92.

37. Kimura K, Sawada T, Komatsu M et al. Antitumor Effect of Trastuzumab for Pancreatic Cancer With High HER-2 Expression and Enhancement of Effect by Combined Therapy With Gemcitabine. Clin Cancer Res 2006; 12: 4925-32.

38. Safran H, lannitti D, Ramanathan $R$ et al. Herceptin and Gemcitabine for Metastatic Pancreatic Cancers That Overexpress HER-2/Neu. Cancer Invest 2004; 22: 706-12.

39. Lee $\mathrm{CH}$, Huntsman DG, Cheang MC et al. Assessment of Her-1, Her-2, And Her-3 Expression and Her-2 Amplification in Advanced Stage Ovarian Carcinoma. Int J Gynecol Pathol 2005; 24: 147-52.

40. Hebbar M, Wacrenier A, Desauw C, et al. Lack of usefulness of epidermal growth factor receptor expression determination for cetuximab therapy in patients with colorectal cancer. Anticancer Drugs. 2006 Aug;17:855-7.

41. Aerts HJ, Dubois L, Perk L, et al. Disparity Between In Vivo EGFR Expression and 89ZrLabeled Cetuximab Uptake Assessed with PET. J Nucl Med. 2008;50:123-131

42. Aerts HJ, Dubois L, Hackeng et al. Development and evaluation of a cetuximab-based imaging probe to target EGFR and EGFRvIll. Radiother Oncol. 2007;83:326-32.

43. Linardou H, Dahabreh IJ, Kanaloupiti D, et al. Assessment of somatic k-RAS mutations as a mechanism associated with resistance to EGFR-targeted agents: a systematic review and meta-analysis of studies in advanced non-small-cell lung cancer and metastatic colorectal cancer. Lancet Oncol. 2008;9:962-72. 


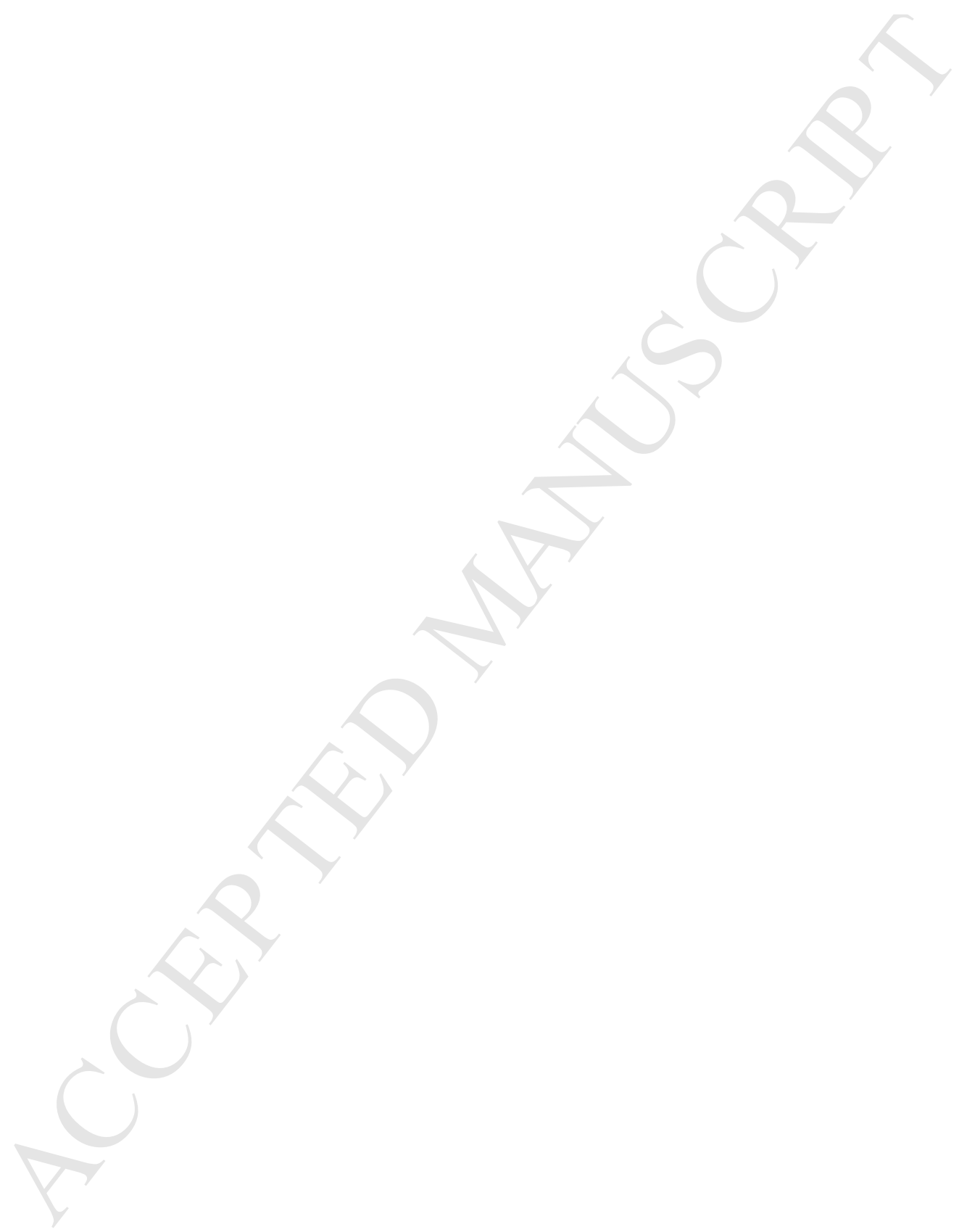


Table 1. Summary of antibodies and methods used in the current study

\begin{tabular}{|c|c|c|c|c|c|}
\hline Antigen & Antibody & Dilution & Incubation & $\begin{array}{l}\text { Antigen } \\
\text { retrieval }\end{array}$ & $\begin{array}{l}\text { Positive } \\
\text { control }\end{array}$ \\
\hline HER-1 & $\begin{array}{l}\text { NCI-L-EGF-r } \\
\text { (Novocastra) }\end{array}$ & $1: 400$ & $15^{\prime}$ at RT & $20^{\prime}$ at $100^{\circ} \mathrm{C}$ & $\begin{array}{l}\text { Oral cavity } \\
\text { epithelium }\end{array}$ \\
\hline HER-2 & $\begin{array}{l}\text { HercepTest } \\
\text { (DAKO) }\end{array}$ & $\begin{array}{l}\text { Ready to } \\
\text { use }\end{array}$ & $30^{\prime}$ at RT & $40^{\prime}$ at $100^{\circ} \mathrm{C}$ & $\begin{array}{l}\text { HER-2 } \\
\text { amplified breast } \\
\text { cancer }\end{array}$ \\
\hline HER-3 & $\begin{array}{l}\text { MAb-MS-725-P } \\
\text { (Neomarkers) }\end{array}$ & $1: 40$ & Overnight $4{ }^{\circ} \mathrm{C}$ & None & Striated muscle \\
\hline HER-4 & $\begin{array}{l}\text { MAb-MS-637-P } \\
\text { (Neomarkers) }\end{array}$ & $1: 40$ & Overnight $4{ }^{\circ} \mathrm{C}$ & None & Striated muscle \\
\hline
\end{tabular}


Table 2. Clinicopathological data of $\mathbf{4 5}$ patients with pancreatic cancer.

\begin{tabular}{|c|c|}
\hline & $\mathbf{N}$ \\
\hline $\begin{array}{l}\text { Sex } \\
\text { male } \\
\text { female }\end{array}$ & $\begin{array}{l}26 \\
19\end{array}$ \\
\hline $\begin{array}{l}\text { Localization } \\
\text { head } \\
\text { body/tail } \\
\text { papilla of Vater }\end{array}$ & $\begin{array}{c}26 \\
6 \\
13\end{array}$ \\
\hline $\begin{array}{l}\text { Type of surgery } \\
\text { Pancreaticoduodenectomy } \\
\text { Distal/total } \\
\text { pancreatectomy } \\
\text { Incision biopsy }\end{array}$ & $\begin{array}{c}38 \\
4 \\
3\end{array}$ \\
\hline $\begin{array}{l}\text { Margins* } \\
\text { Free } \\
\text { Microscopically involved } \\
\text { Macroscopically involved }\end{array}$ & $\begin{array}{c}21 \\
17 \\
1\end{array}$ \\
\hline \begin{tabular}{cl}
\multicolumn{3}{l}{ Stage } & ** \\
I & $(\mathrm{T} 1-2, \mathrm{~N} 0, \mathrm{M} 0)$ \\
II & $(\mathrm{T} 3, \mathrm{~N} 0, \mathrm{M} 0)$ \\
III & $(\mathrm{T} 1-3, \mathrm{~N} 1, \mathrm{M} 0)$ \\
IVa & $(\mathrm{T} 4, \mathrm{~N} 0-1, \mathrm{M} 0)$ \\
IVb & $(\mathrm{T} 4, \mathrm{~N} 0-1, \mathrm{M} 1)$ \\
\end{tabular} & $\begin{array}{c}3 \\
8 \\
30 \\
1 \\
-\end{array}$ \\
\hline $\begin{array}{l}\text { Grade } \\
\text { well-differentiated } \\
\text { moderately differentiated } \\
\text { poorly differentiated }\end{array}$ & $\begin{array}{l}13 \\
15 \\
17\end{array}$ \\
\hline
\end{tabular}

* Margins of 3 cases with biopsy only and 3 other cases could not be determined.

** Stage was classified according to TNM-classification of the UICC, $5^{\text {th }}$ edition 1997.

The stage of the three cases with biopsies only could not be determined. 
Table 3. HER-2 family expression and amplification in $\mathbf{4 5}$ cases of pancreatic cancer

\begin{tabular}{|c|c|c|}
\hline & $\mathrm{N}$ & $\%$ \\
\hline $\begin{array}{l}\text { HER-1 } \\
\text { overexpression } \\
\text { Absent } \\
\text { Present }\end{array}$ & $\begin{array}{c}45 \\
0\end{array}$ & $\begin{array}{c}100 \\
0\end{array}$ \\
\hline $\begin{array}{l}\text { HER-2 } \\
\text { overexpression } \\
\text { Absent } \\
\text { Present }\end{array}$ & $\begin{array}{c}45 \\
0\end{array}$ & $\begin{array}{c}100 \\
0\end{array}$ \\
\hline $\begin{array}{l}\text { HER-2 amplification* } \\
\text { Absent } \\
\text { Present }\end{array}$ & $\begin{array}{c}45 \\
0\end{array}$ & $\begin{array}{c}100 \\
0\end{array}$ \\
\hline $\begin{array}{l}\text { HER-3 expression } \\
\text { negative } \\
1+ \\
2+ \\
3+\end{array}$ & $\begin{array}{c}12 \\
21 \\
8 \\
4\end{array}$ & $\begin{array}{c}27 \\
47 \\
17 \\
9\end{array}$ \\
\hline $\begin{array}{l}\text { HER-4 } \\
\text { overexpression } \\
\text { negative } \\
1+ \\
2+ \\
3+\end{array}$ & $\begin{array}{c}4 \\
4 \\
21 \\
16\end{array}$ & $\begin{array}{c}9 \\
9 \\
47 \\
35\end{array}$ \\
\hline
\end{tabular}

* 5 by $\mathrm{CISH}, 40$ by MLPA 
Figure 1. Immunohistochemistry examples of pancreatic adenocarcinoma. A HER-1 shows no expression; B 1+ expression of HER-2; C and D strong expression of HER-3 and HER-4 in normal pancreatic tissue, but no expression in pancreatic adenocarcinoma, respectively. 


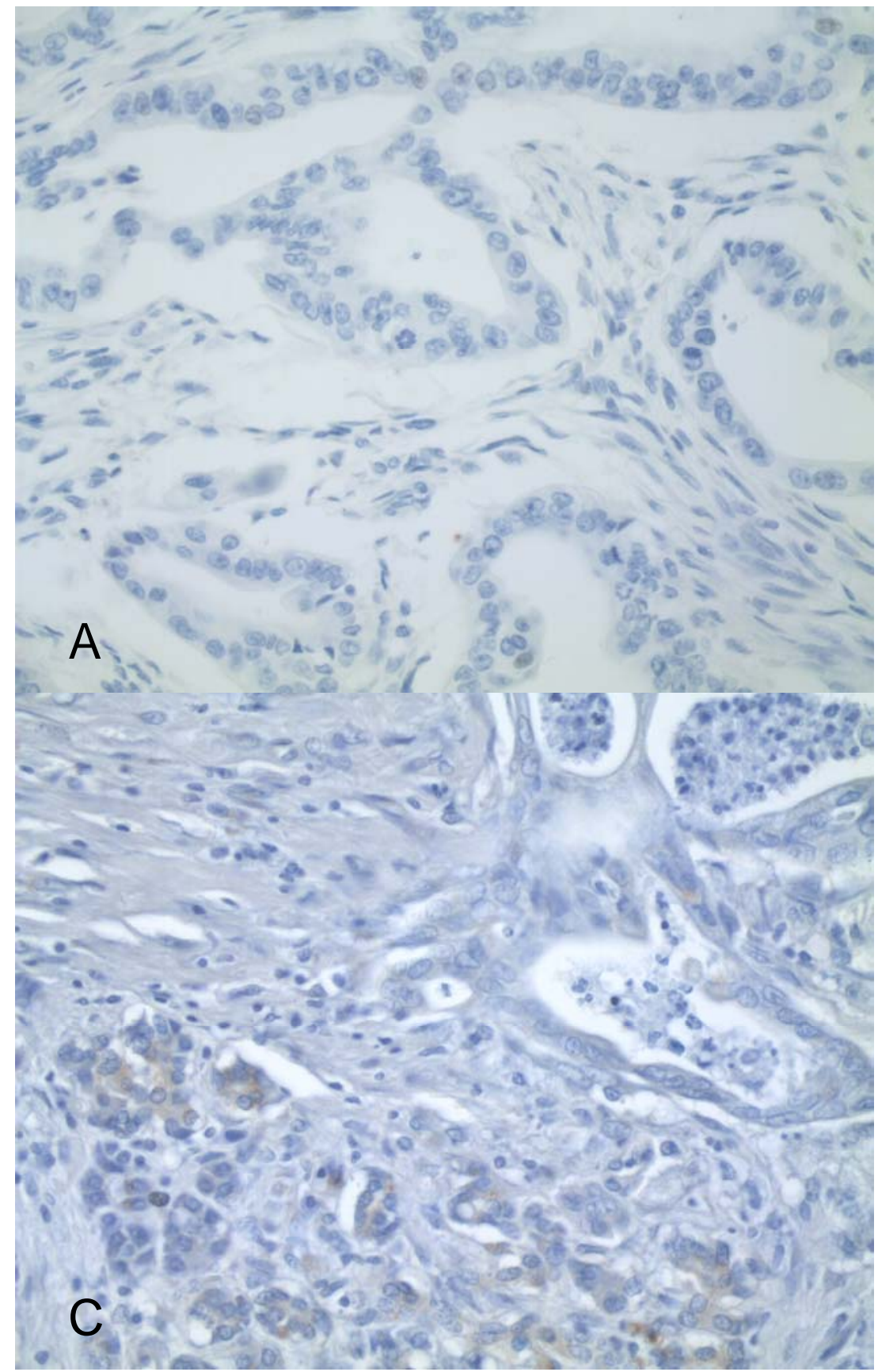

B

Figure 1. Immunohistochemistry examples of pancreatic adenocarcinoma. A HER-1 shows no expression; B 1+ expression of HER-2; C and D strong expression of HER-3 and HER-4 in normal pancreatic tissue, respectively, but no expression in pancreatic adenocarcinoma. 


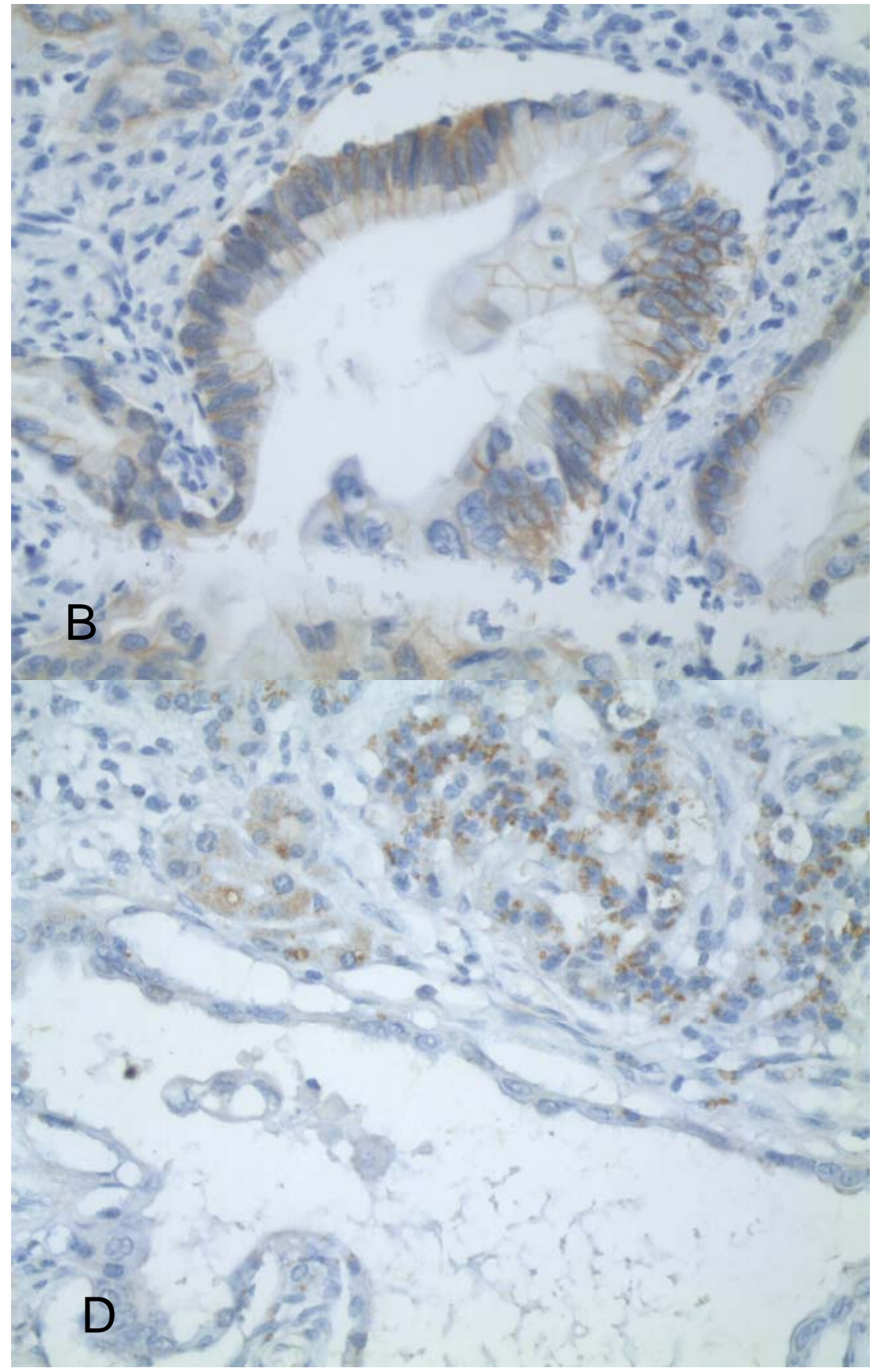

